Jurnal ABDIMAS INDEPENDEN

Vol. 1, No. 2, November 2020

\title{
PELATIHAN PENINGKATAN INKLUSI KEUANGAN DAN PERLUASAN PASAR PRODUK BAGI PEREMPUAN PENGRAJIN KASUR KAPUK DI DESA SANDIK KABUPATEN LOMBOK BARAT
}

\author{
Taufik Chaidir ${ }^{1 *}$, Ida Ayu Putri S , Gst Ayu Arini,Baiq Ismiwati \\ Jurusan Ilmu Ekonomi dan Studi Pembangunan - Universitas Mataram \\ taufiqch.feunram@gmail.com
}

\begin{abstract}
ABSTRAK
Peningkatan inklusi keuangan dan perluasan pasar produk merupakan cara yang dapat dipergunakan oleh pemerintah dan masyarakat dalam mengatasai kemiskinan. Hal ini disebabkan karena dengan inklusi keuangan maka setiap orang dapat memiliki akses dan layanan penuh dari lembaga keuangan secara tepat waktu, nyaman, informatif, dan terjangkau biayanya dengan penghormatan penuh kepada harkat dan martabatnya. Sedangkan perluasan pasar produk yang dihasilkan pengusaha diharapkan dapat meningkatkan penjualan yang pada akhirnya dapat meningkatkan pendapatan, tabungan masyarakat, pertumbuhan ekonomi yang pada akhirnya dapat mengurangi jumlah penduduk miskin. Oleh karenanya tujuan dari pengabdian ini adalah meningkatkan inklusi keuangan dan perluasan pasar produk bagi perempuan pengrajin kasur kapuk Di Desa Sandik Kabupaten Lombok Barat. Pengabdian ini merupakan kelanjutan hasil pengabdian yang telah dilaksanakan pada tahun 2018 yang diperlukan oleh sasaran target. Metode yang digunakan dalam kegiatan ini pertama observasi,kedua memberikan penyuluhan terkait dengan peningkatan inklusi keuangan dan perluasan pasar produk ketiga, memberikan pendampingan untuk memperluas pasar produk. Hasil kegiatan, peserta bersedia menularkan pengetahuan yang diperolehnya pada penrgrajin yang lain diseputar tempat mereka tinggal, adanya keinginan dari peserta untuk membentuk kelompok usaha guna mempermudah aksesibilitas dalam memperoleh modal, bimbingan tekhnis dalm proses produksi,design produk dan pemasaran secara online.
\end{abstract}

Kata Kunci: Inklusi Keuangan, Perluasan Produk, Kemiskinan 


\begin{abstract}
Increasingfinancial inclusion and expanding the market for products are two of many ways that can be used by the government and the peopleto overcome the poverty. By financial inclusion, everyone can have full access to and services from financial institutions on timely, comfortable, informative, and affordable manner with full respect for their dignity. While the expansion of the market for products produced by entrepreneurs is expected to increase sales which can increase the income, public savings, and economic growth so that can reduce the number of poor people. Therefore, the aim of this service is to increase financial inclusion and expand the product market for cotton mattress craftswomen in Sandik Village, West Lombok District. This service is a continuation of the results of the service that was carried out in 2018 which were required. The method used in this activity is first, observation. The second is to provide counseling related to increasing financial inclusion and market expansion for the product.Third method is providing assistance to expand the product market. As a result of the activity, participants are willing to pass on the knowledge they have acquired to other craftsmen around where they live, the desire of participants to form business groups to facilitate accessibility in obtaining capital, technical guidance in the production process, product design and online marketing.
\end{abstract}

Keywords: Financial Inclusion, Product Expansion, Poverty

\title{
PENDAHULUAN
}

Berdasarkan hasil pengabdin yang telah dilaksanakan oleh tim pengabdian pada tahun 2018, diketahui bahwa pengrajin kasur di desa Sandik Kabupaten Lombok Barat melakukan proses produksi secara tradisional artinya bahwa apa yang mereka dapatkan dari pengalaman pengrajin sebelumnya baik dari keluarga atau kerabat selalu menjadi contoh bagi mereka untuk berproduksi, mereka sangat kurang untuk melakukan inovasi hal ini berdampak pada kualitas produk, pemasaran dan harga produk yang dihasilkan relative murah, sehingga sangatlah sulit untuk dapat meningkatkan kesejahteraannya. Disamping itu mereka tidak memahami pentingnya inklusi keuangan yang harus dimiliki oleh seorang pengusaha guna meningkatkan kegiatan ekonominya. Akibat keterbatasn tersebut bedampak pada rendahnya pendapatan yang dimiliki pengrajin, yaitu tidak lebih dari Rp 200,000, per bulan, keuntungan ini 


\section{Jurnal ABDIMAS INDEPENDEN}

Vol. 1, No. 2, November 2020

tentunya tidak cukup untuk memenuhi kebutuhan rumah tangganya akibatnya mereka selalu tetap dalam kondisi yang kurang atau tidak sejahtera. Oleh karenanya Tim pengabdian berusaha untuk melakukan pendampingan lanjutan terkait dengan upaya - upaya yang dilakukan agar pengrjin memiliki pengetahuan tentang inklusi keungan dan perluasan pasar produk yang dihasilkan. Hal ini disebabkan karena inklusi keuangan merupakan salah satu cara yang dapat dipergunakan oleh pemerintah sebagai instrument dalam mengatasai kemiskinan. Hal ini disebabkan karena inklusi keuangan berdasarkan pada Strategi Nasional Keuangan Inklusif dari Bank Indonesia ( Bank Indonesia, 2014) adalah hak setiap orang untuk memiliki akses dan layanan penuh dari lembaga keuangan secara tepat waktu, nyaman, informatif, dan terjangkau biayanya dengan penghormatan penuh kepada harkat dan martabatnya. Berdasarkan pada definisi ini diharapakan dengan adanya peningkatan inklusi keuangan terjadinya peningakatan tabungan masyarakat, perluasan pasar produk, pertumbuhan ekonomi relative tinggi yang pada akhirnya dapat mengurangi jumlah penduduk miskin dan meningkatkan kesejahteraan masyarakat.

Tim menyadari bahwa kesejahteraan masyarakat merupakan suatu keniscayaan yang harus selalu ditingatkan karena kesejahteraan merupakan salah satu hak bagi setiap warga negara, namun sayangnya kesejahteraan itu akan sulit terwujud tanpa adanya intervensi baik dari pemerintah maupun dari masyarakat. Kesejahteraan dapat diukur dari sisi moneter ( pendapatan) dan non moneter ( Lincolin Arsyad, 2010). Oleh karenanya tim pengabdian berharap dapat membantu pengrajin khususnya untuk dapat meningkatkan kesejahteraannya. Meningkatnya kesejahteraan pengrajin ini diharapkan dapat memberikan kontribusi terhadap penurunan angka kemiskinan di Provinsi Nusa Tenggara Barat mengingat kemiskinan menjadi salah satu masalah yang dihadapi oleh pemerintah Provinsi Nusa Tenggara Barat dimana angka kemiskinan tidak pernah mencapai target yang ditetapkan seperti terlihat pada tabel 1.1. 
Tabel 10: Jumlah Penduduk Miskin , Persentase Penduduk Miskin dan Target RPJMD

\begin{tabular}{|c|c|c|c|}
\hline \multirow{2}{*}{ Tahun } & \multirow{2}{*}{ Penduduk Miskin } & \multicolumn{2}{|c|}{ \% Penduduk Miskin } \\
\cline { 3 - 4 } & 1.050 .948 & Realisasi & Target RPJMD \\
\hline 2009 & 1.009 .352 & 21,55 & 22,1 \\
\hline 2010 & 894.770 & 19,73 & 20 \\
\hline 2011 & 828.330 & 18,02 & 18 \\
\hline 2012 & 802.45 & 17,52 & 16 \\
\hline 2013 & 816.621 & 17,05 & 14 \\
\hline 2014 & 802.290 & 16,54 & 16,25 \\
\hline 2015 & 786.580 & 16,02 & 14,25 \\
\hline 2016 & 748.120 & 15,05 & 13,25 \\
\hline 2017 & 735.620 & 14,63 & 12,25 \\
\hline 2018 & &
\end{tabular}

Sumber: BPS NTB, RPJMD Prov NTB , 2009-2018

Pada tabel di atas dapat dilihat bahwa sepanjang periode $2009-2018$ jumlah penduduk miskin cenderung menurun namun demikian tidak terjadi perubahan yang significant terhadap "head count index" dan bahkan sepanjang periode tersebut gap antara realisasi dan target RPJMD semakin besar. Oleh karenanya diperlukan kerja keras secara bersama- sama untuk mengatasi hal tersebut karena kemiskinan merupakan masalah yang sangat komplek (Mudrajat Kuncoro, 2006).

Berdasarkan pada paparan diatas bila dilihat kondisi perempuan pengrajin kasur kapuk di desa Sandik dapat dikelompokkan pada penduduk yang rentan dalam kelompok penduduk miskin. Hal ini terindikasi dari tingkat penghasilannya sebagai pengrajin kasur kapuk yang relative rendah. Rendahnya tingkat penghasilan pengrajin ini disebabkan karena faktor internal dan esksternal. Salah satu faktor internal tersebut adalah pengrajin tidak mempunyai pengetahuan terkait dengan inklusi keuangan, dan pasar produk mereka yang sangat terbatas., sehingga perluasan pasar yang merupakan salah satu aspek 


\section{Jurnal ABDIMAS INDEPENDEN}

Vol. 1, No. 2, November 2020

pemasaran menjadi sebuah keharusan dilakukan (Kotler,P. \& Keller,K.L, 2008). Sedangkan fakor eksternal yang mempengaruhi adalah berkembangnya kasur yang terbuat dari kasur non kapuk seperti spring bed dan kasur pegas yang menyebabkan tingkat persaingan pasar yang dihadapi oleh pengrjin kasur berbahan kapuk menjadi semakin meningkat, sehingga perlu dikaji pasar potensial dan bagaimana melakukan pemasaran untuk produk kasur dari kapuk dan bagaimana meningkatkan pengetahuan tentang inklusi keuangan.

Berdasarkan pada paparan diatas maka diperlukan upaya untuk meningkatkan daya saing pengrajin dan diharapkan dapat meningkatkan kesejahteraan pengrajin sehingga untuk itu diperlukan melakukan pengabdian masyarakat terkait Pelatihan Peningkatan Pengetahuan Tentang Inklusi Keuangan dan Perluasan Pasar Produk bagi perempuan pengrajin kasur kapuk Di Desa Sandik Kabupaten Lombok Barat

\section{METODE KEGIATAN}

Metode pemecahan masalah yang digunakan dalam kegiatan ini adalah :

a. Observasi

Observasi kepada sasaran target dilakukan untuk memastikan permasalahan yang dihadapi oleh sasaran target dalam hal ini perempuan pengrajin kasur kapuk di Desa Sandik Kabupaten Lombok Barat. Observasi lapangan ini dilaksanakan pada saat tim melakukan pengabdian pada tahun 2018.di lokasi tersebut. Oleh karenanya, permasalahan yang dihadapi sasaran target sudah dipastikan keakuratannya karena permasalahan ini telah dikonfirmasi oleh tim kepada sasaran target dan kepala Dusun Perempung Lama Desa Sandik pada saat melaksanakan pengabdian tahun 2018.

b. Penyuluhan

Penyuluhan ditujukan untuk meningkatkan inklusi keuangan dan perluasan pasar produk bagi perempuan pengrajin kasur kapuk. Adapun materi yang disampaikan adalah pentingnya Inklusi keuangan dan sumber 
permodalan, diversifikai produk, efisiensi proses produksi dan pentingnya perlusan pasar

c. Pendampingan

Pendampingan selama dua minggu merupakan metode terakhir yang diterapkan dalam kegiatan pengabdian kepada masyarakat ini, ditujukan untuk memastikan dan menguatkan perluasan pasar produk yang dihasilkan oleh pengrajin sehingga diharapkan pengrajin dapat mngembangkan usahanya yang pada akhirnya mampu meningkatkan kesejahteraannya.

\section{PEMBAHASAN}

1. Hasil dan Pembahasan Observasi

Pelaksanaan kegiatan pengabdian kepada masyarakat ini diawali dengan kegiatan observasi terhadap sasaran target yang dilaksanakan pada tahun 2018 , pada saat itu Tim melaksanakan pengabdian masyrakat pada lokasi tersebut sehingga hasil obervasi dapat menjadi akurat. Hal ini disebabkan karena tim pengabdian langsung mengkonfirmasi kepada sasaran target dan kepala Dusun Perempung Lama Desa Sandik terkait dengan permasalahan yang dihadapi oleh perempuan pengrajin kasur kapuk. Berdasarkan hasil observasi tersebut terindentifikasi permasalahnnya adalah a) perempuan pengrajin kasur kapuk melakukan kegiatan usahanya secara turun temurun sehingga diversifikasi produk tidak terjadi b) Perempuan pengrajin kasur kapuk tidak memiliki pengetahuan yang cukup mengenai inklusi keuangan dan pasar produknya sangat terbatas. 


\section{Jurnal ABDIMAS INDEPENDEN}

Vol. 1, No. 2, November 2020

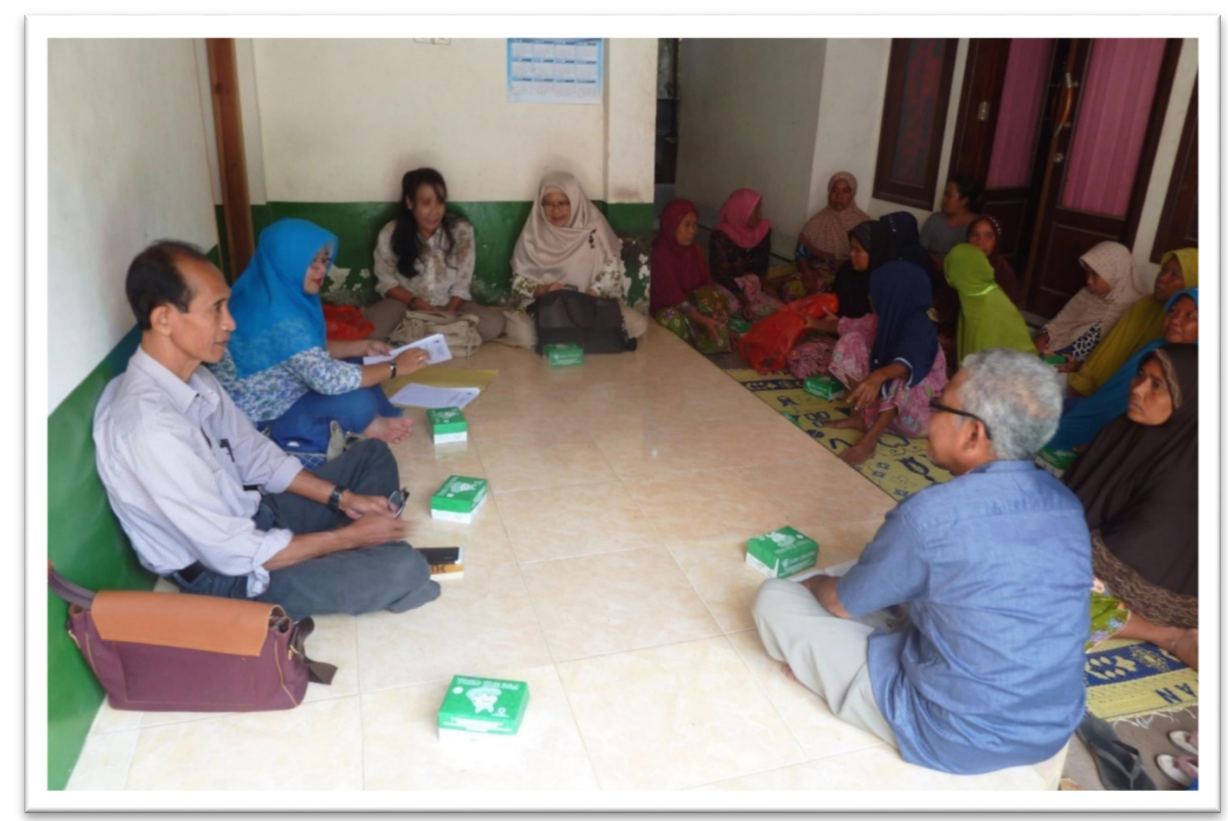

\section{Gambar 1 : Suasana Observasi dan Confirmasi Permasalahan yang dihadapi Oleh Perempuan Pengrajin Kasur}

2. Hasil dan Pembahasan Penyuluhan

Penyuluhan ini dilaksanakan oleh oleh Tim pengabdian dan diikuti oleh perempuan pengrajin kasur kapuk dan Kepala Dusun Perempung Lama yang berlokasi dirumah Kepala Dusun Perempung Lama. Materi penyuluhan yang disampaikan meliputi; pentingnya Inklusi keuangan dan sumber permodalan, diversifikai produk, efisiensi proses produksi dan pentingnya perlusan pasar.

Adapun indicator keberhasilan dalam kegiatan pengabdian ini adalah sebagai berikut :

a) Jumlah peserta melebehi target yang ditetapkan yaitu 31 orang (155\%) dari target yang ditetapkan sebanyak 20 orang hal ini mengindikasikan tingginya minat peserta untuk mengikuti kegitan ini

b) Keaktifan peserta saat pelatihan cukup tinggi . Hal ini terlihat dari berbagai pertanyaan yang disampikan terutama mengenai inklusi keuangan, design produk, pemasaran on line. 
c) Peserta bersedia menularkan pengetahuan yang diperolehnya pada penrgrajin yang lain diseputar tempat mereka tinggal.

d) Adanya keinginan dari peserta untuk membentuk kelompok usaha guna mempermudah aksesibilitas dalam memperoleh modal, bimbingan tekhnis dalm proses produksi

Sedangkan factor penghambat dari pelaksanaan kegiatan pengabdian ini adalah peserta yang hadir cukup banyak melebihi target yang ditetapkan hal ini cukup membuat kesulitan dalam pengaturan ruangan tempat kegiatan pelaksanaan pengabdian masyarakat.

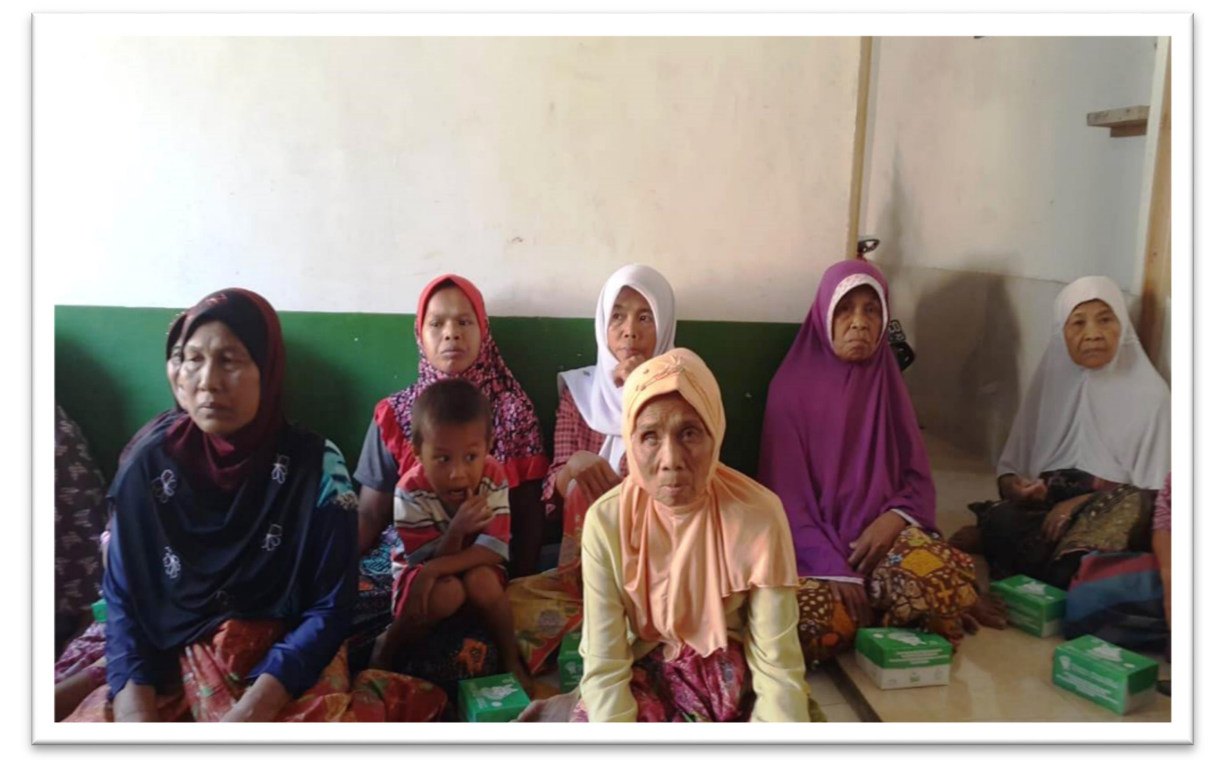

Gambar 2 Suasana Pada Saat Penyuluhan

3. Hasil dan Pembahasan Pendampingan

Pendampingan dilakukan selama dua minggu untuk memastikan kegiatan pengabdian pada masyarakat ini telah mampu meningkatkan pengetahuan perempuan pengrajin terkait dengan inklusi keuangan serta dapat memastikan rencana perluasan pasar melalui system online oleh perempuan pengrajin kasur kapuk. Dengan pendampingan ini memungkinkan tim dapat menemukan potensi kendala ataupun potensi 


\title{
Jurnal ABDIMAS INDEPENDEN
}

\author{
Vol. 1, No. 2, November 2020
}

solusi serta potensi pengembangan terhadap produk yang dihasilkan oleh perempuan pengrajin kasur kapuk.

\section{KESIMPULAN DAN SARAN}

\section{Kesimpulan}

Berdasarkan hasil kegiatan pelaksanaan pelatihan peningkatan inklusi keuangan dan perluasan pasar produk bagi perempuan pengrajin kasur kapuk Di Desa Sandik Kabupaten Lombok Barat dapat disimpulkan sebagai berikut :

1. Tidak ditemui hambatan di dalam penyelenggaraan pelatihan disebabkan adanya kerjasama yang sangat baik antara tim penyuluh dengan kepala Dusun Perempung Lama sehingga peserta dapat mengikuti acara pelatihan tepat waktu.

2. Kehadiran peserta cukup tinggi yakni 31 orang lebih besar dari target yang ditetapkan sebanyak 20 orang (155\%).

3. Keaktifan peserta saat pelatihan cukup tinggi . Hal ini terlihat dari berbagai pertanyaan yang disampikan terutama mengenai inklusi keuangan, design produk dan perluasan pasar

4. Peserta bersedia menularkan pengetahuan yang diperolehnya pada pengrajin diseputar tempat mereka tinggal.

5. Pengrajin kesulitan didalam membuat design produk dan memperluas pasar produk mereka

6. Adanya keinginan dari peserta untuk membentuk kelompok usaha guna mempermudah aksesibilitas dalam memperoleh modal maupun dalam memperoleh bantuan teknis dalam proses produksi dan pemasaran

Saran

1. Perlu dilakukan penguatan kapasitas terkait dengan inklusi keuangan sehingga pengrajin dapat mengakses permodalan 
2. Pengrajin perlu memiliki kelompok usaha guna memperoleh bantuan terkait dengan kualitas dan design produk serta perluasan pasar

3. Instansi terkait ( Dinas Perindustrian, Dinas Perdagangan, Dinas Koperasi dan Usaha Kecil) harus melakukan pembinaan dan pendampingan terhadap pengrajin sehingga proses produksi dapat berjalan secara efisien, kualitas produk lebih meningkat, diversifikasi produk serta perluasan pasar dapat berkembang.

\section{UCAPAN TERIMA KASIH}

Pada kesempatan ini Tim Pengabdian kepada Masyarakat menyampaikan ucapan terima kasih yang sebesar-besarnya atas bantuan dan dukungan dari berbagai pihak sehingga pengabdian ini dapat berlangsung dengan baik. Terima kasih diucapkan kepada :

1. Rektor Universitas Mataram

2. Dekan Fakultas Ekonomi dan Bisnis Universitas Mataram

3. Ketua Lembaga Pengabdian Kepada Masyarakat Universitas Mataram

4. Ketua BP2EB Fakultas Ekonomi dan Bisnis Universitas Mataram

5. Kepala Dusun Perempung dan perempuan pengrajin kasur yang menjadi subjek pengabdian ini.

\section{DAFTAR PUSTAKA}

Booklet Keuangan Inklusif, Departemen Pengembangan Akses Keuangan dan UMKM BI, 2014

Arsyad Lincolin, Ekonomi Pembangunan Edisi 5, STIM YKPN Yogyakarta, 2010

Kotler,P. \& Keller,K.L. (2008). Manajemen Pemasaran, Edisi 12 Jilid 2. Alih Bahasa Benyamin Molan. Penerbit PT Indeks: Jakarta

Kuncoro Mudrajat.(2006).Ekonomi Pembangunan, Teori, Masalah , dan Kebijakan, UPP STIM YKPN, Yogyakarta 